\title{
Disposable electrochemical flow cells for catalytic adsorptive stripping voltammetry (CAdSV) at a bismuth film electrode (BiFE)
}

\author{
Nahid Gharib Naseri • Sara J. Baldock • \\ Anastasios Economou • Nicholas J. Goddard • \\ Peter R. Fielden
}

Received: 31 October 2007 /Revised: 31 January 2008 / Accepted: 6 February 2008 / Published online: 20 March 2008

(C) The Author(s) 2008

\begin{abstract}
Catalytic adsorptive stripping voltammetry (CAdSV) has been demonstrated at a bismuth film electrode (BiFE) in an injection-moulded electrochemical micro-flow cell. The polystyrene three-electrode flow cell was fabricated with electrodes moulded from a conducting grade of polystyrene containing $40 \%$ carbon fibre, one of which was precoated with $\mathrm{Ag}$ to enable its use as an on-chip $\mathrm{Ag} / \mathrm{AgCl}$ reference electrode. CAdSV of $\mathrm{Co}(\mathrm{II})$ and $\mathrm{Ni}$ (II) in the presence of dimethylglyoxime (DMG) with nitrite employed as the catalyst was performed in order to assess the performance of the flow cell with an in-line plated BiFE. The injectionmoulded electrodes were found to be suitable substrates for the formation of BiFEs. Key parameters such as the plating solution matrix, plating flow rate, analysis flow rate, solution composition and square-wave parameters have been characterised and optimal conditions selected for successful and rapid analysis of $\mathrm{Co}$ (II) and $\mathrm{Ni}$ (II) at the ppb level. The analytical response was linear over the range 1 to $20 \mathrm{ppb}$ and deoxygenation of the sample solution was not required. The
\end{abstract}

\footnotetext{
N. Gharib Naseri $\cdot$ S. J. Baldock $(\bowtie) \cdot$ A. Economou •

N. J. Goddard $\cdot$ P. R. Fielden

School of Chemical Engineering and Analytical Science,

University of Manchester,

P.O. Box 88, Manchester M60 1QD, UK

e-mail: sara.baldock@manchester.ac.uk

N. Gharib Naseri

Petroleum University of Technology,

P.O. Box 63431, Kut Abdualah, Ahwaz-Abadan Rd.,

Ahwaz, Iran

\author{
A. Economou \\ Laboratory of Analytical Chemistry, Department of Chemistry, \\ University of Athens,
}

Athens 157 71, Greece
}

successful coupling of a microfluidic flow cell with a BiFE, thereby forming a "mercury-free" AdSV flow analysis sensor, shows promise for industrial and in-the-field applications where inexpensive, compact, and robust instrumentation capable of low-volume analysis is required.

Keywords Bismuth film electrode (BiFE) - Square-wave adsorptive stripping voltammetry Cobalt $\cdot$ Nickel .

Dimethylglyoxime $\cdot$ Electrochemical detection $\cdot$ Flow cell . Channel $\cdot$ Injection moulding $\cdot$ Sensor

\section{Introduction}

Mercury electrodes, normally in the form of mercury films for flow systems, have been widely used for performing stripping voltammetry as a result of their high sensitivity and reproducibility, but, due to increasing concern and legislation regarding the toxicity of mercury, alternative working electrode (WE) materials have been investigated. Metals such as Au [1, 2], Ag [2, 3], Ir [4] and even W [5] as well as bare and coated carbon electrodes $[6,7]$ have all been investigated for stripping analysis of metals.

In 2000, bismuth-film electrodes [8] were mooted as a replacement for mercury-film electrodes, as bismuth exhibits negligible toxicity and is more environmentally friendly in comparison. Mercury use is increasingly regulated, motivating the search for mercury-free methods. For example, Sweden banned the sale of switches, apparatuses and instruments containing mercury in 1993 (Ordinance SFS 1991:1290) and instructed the Swedish Chemicals Inspectorate (KemI) to look into a total ban on the handling of mercury in Sweden, including chemicals used for analysis. The Inspectorate proposed that mercury for 
chemical analysis should be exempted from the general ban until 31st December 2008 in order to enable the development and implementation of mercury-free analysis methods [9]. In 2005 the EU commission proposed a ban on mercury exports by 2011 as part of a strategy to reduce mercury emissions and protect against exposure [10], and recently MEPs voted to bring this date forward to 2010 [11].

A variety of substrates have been used for bismuth films. While platinum [12-14] and gold [13] have both been investigated, the majority of films have been deposited on carbon substrates. Most studies have used glassy carbon $[8$, 13, 15-32], though wax-impregnated graphite [22, 24], pencil-lead graphite [33], carbon paste [13, 34-36], screenprinted carbon inks [21, 37, 38], carbon fibres [8, 13, 14] and boron-doped diamond [39] have all been employed as substrates. The use of $\mathrm{Bi}_{2} \mathrm{O}_{3}$ containing pastes $[34,40]$ and a bismuth bulk electrode [41] have also been reported.

The use of BiFE has recently been reviewed [42]. Bismuthfilm electrodes have mainly been applied to anodic stripping voltammetry (ASV) and adsorptive stripping voltammetry (AdSV) techniques for metal ion analysis, although cathodic detection of nitrophenols [17, 27, 41] and amperometric detection of glucose [12] have also been reported. Cd [28], $\mathrm{Pb}[18,37], \mathrm{Zn}[31,32]$ and mixtures of all three ions [8, 20, $22,23,33,36,41]$ have been the most extensively studied by ASV. Tl, Cu [16], In [16, 43], Mn [39] and Sn [44] have also been analysed. Fewer reports have been made employing AdSV, though Ni [15] and Co [28-30] and Ni with Co [24, $26]$ have been examined using dimethylglyoxime (DMG). $\mathrm{Cr}$ [21, 25, 45], U [46, 47], $\mathrm{Al}$ [48], $\mathrm{V}$ [49] and Mo [50] analysis by AdSV on bismuth-film electrodes has also been performed.

Stirred solutions have normally been used, though Economou et al. have reported the use of a rotating disc electrode [22-25] and a Nafion-coated BiFE in a thin layer flow cell $(0.5 \mathrm{~mm}$ spacer) for sequential injection-ASV of metals [51, 52]. Hutton et al. generated an in-situ BiFE in a thin layer $(0.3 \mathrm{~mm}$ spacer) flow cell (Bioanalytical Systems Inc., West Lafayette, IN, USA) for flow injection analysis of nitrophenols with cathodic amperometric detection [27].

Adsorptive stripping voltammetry of DMG-complexed $\mathrm{Co}$ and $\mathrm{Ni}$ has found widespread use in trace metal analysis. The enhancement of the Co-DMG response using nitrite, i.e. catalytic adsorptive stripping voltammetry (CAdSV), has also been the subject of several publications, for example van den Berg et al. [53, 54] and the review of catalytic systems by Bobrowski and Zarębski [55]. CAdSV of $\mathrm{Co}$ on a BiFE was reported by Krolicka et al. [29, 30] using an ex situ plated film on glassy carbon. Most BiFEs have been plated from acetic buffers, although Krolicka et al. used a plating solution of $\mathrm{Bi}\left(\mathrm{NO}_{3}\right)_{3}(0.02 \mathrm{M}), \mathrm{LiBr}$ $(0.5 \mathrm{M})$, and $\mathrm{HCl}(1 \mathrm{M})$ with a plating potential of $-0.25 \mathrm{~V}$ for $45 \mathrm{~s}$ [addition of bromide and strong acid enabled a highly concentrated $\mathrm{Bi}(\mathrm{III})$ plating solution to be produced]. Stripping was typically carried out in $0.1 \mathrm{M}$ ammonia buffer $\left(\mathrm{pH}\right.$ 9.2) containing DMG $\left(1 \times 10^{-4} \mathrm{M}\right)$ and $\mathrm{NaNO}_{2}$ $(0.5 \mathrm{M})$. Voltammograms were recorded in the differential pulse mode and a 15 -fold enhancement of the Co-DMG stripping signal was reported.

Recently the authors reported the use of $40 \%$ carbon fibre-filled nylon 6/6 injection-moulded electrodes as working electrodes for the determination of $\mathrm{Cu}$ (II) by $\mathrm{CV}$ and ASV techniques [56].

In this work, the electrodes were moulded from a $40 \%$ carbon fibre-filled polystyrene, which was also found to be suitable for performing electrochemical detection. This paper presents the first report of the use of CAdSV at an in-line plated BiFE in an integrated three-electrode injection-moulded plastic micro flow cell.

\section{Experimental}

\section{Instrumentation}

Voltammetric measurements were performed using an Autolab electrochemical system (PSTAT 10, Eco Chemie B.V., Utrecht, The Netherlands) controlled with GPES software (v4.6, Eco Chemie) running on a PC.

\section{Rotating disc electrode experiments}

The rotating disc electrode (RDE) was a glassy carbon electrode (6.1204.000, Metrohm, Buckingham, UK) $3 \mathrm{~mm}$ in diameter controlled with a variable speed (500-3000 rpm) electrode rotator (Part No. 628-10, Metrohm). The disc electrode was polished with an alumina slurry $(0.3 \mu \mathrm{m}$ $\mathrm{Al}_{2} \mathrm{O}_{3}$, Metrohm) before use. A standard $(12 \mathrm{~mm}$ in diameter) glass double junction $\mathrm{Ag} / \mathrm{AgCl} / \mathrm{KCl}(3 \mathrm{M})$ reference electrode was used (CR4/DJ/AG, Thermo Electron, Auchtermuchty, Fife, UK) with a Pt wire auxiliary $0.5 \mathrm{~mm}$ in diameter (99.9\%, Aldrich, Gillingham, UK). The electrodes were mounted in a small-volume 50-ml beaker used as an electrochemical cell.

\section{Flow cell experiments}

A gravity-fed flow system was used comprising a reservoir formed from a disposable syringe body $(20 \mathrm{ml})$, and narrow-bore PTFE tubing (0.032 in. i.d., Lee Products, Gerrards Cross, UK). The flow was controlled with a manual two-way valve (Part No. 2420, Omnifit, Cambridge, UK). Barbed (1/16") polypropylene female Luer fittings (Cole-Parmer, Hanwell, London, UK) enabled connection of the flow system to the injection-moulded 
flow cell. Electrical connection to the Autolab electrochemical system was made using crocodile clips.

\section{Chip fabrication}

The injection-moulded flow cells were produced in-house. Figure 1 depicts the fabricated device showing the three integrated electrodes (WE, reference and auxiliary). Solid models created using AutoCAD (Mechanical Desktop 2004, Autodesk, San Jose, CA, USA) were converted into macro commands for a CNC milling machine (Datron CAT3D M6, Datron Technology, Milton Keynes, UK) to produce the milled aluminium moulds for the injectionmoulding machines (Babyplast $6 / 6$ or $6 / 10$, Cronoplast SL, Barcelona, Spain). A four-stage process was required to manufacture a ready-to-use device. The polymer electrodes were injection moulded (moulding temperature of $220{ }^{\circ} \mathrm{C}$ ) from a conducting polymer ( $40 \%$ carbon-fibre-filled highimpact polystyrene (HIPS), RTP 487, RTP Company (UK) Plastics Ltd., Bury, UK). The reference electrodes were coated with Ag (Ag evaporation slug, 99.99\%, Aldrich) using an e-beam evaporator (Auto500 with EB3 e-beam unit, Edwards High Vacuum International, Crawley, West Sussex, UK) to a thickness of $125 \mathrm{~nm}$. The WE, reference and auxiliary electrodes were then incorporated into the flow cell by an overmoulding procedure. The mould cavity for the flow cell design comprises a base plate into which the preformed electrodes are inserted in the appropriate recesses and a top plate with a relief pattern that forms the flow channel and integrated fluidic connectors. The flow cell was moulded (moulding temperature of $220^{\circ} \mathrm{C}$ ) from crystal polystyrene (Northern Industrial Plastics Ltd. Chadderton, UK). Using a 500-W ultrasonicwelder (Mini delta 9500, FFR Ultrasonics Ltd., Queniborough, Leicestershire, UK), with a weld time of $1 \mathrm{~s}$ and a hold time of $2 \mathrm{~s}$, the top and base plates were sealed together to form a complete and ready-to-use device. The flow channel dimensions were $1 \mathrm{~mm}$ wide, $1 \mathrm{~mm}$ deep and $30 \mathrm{~mm}$ long. The working and

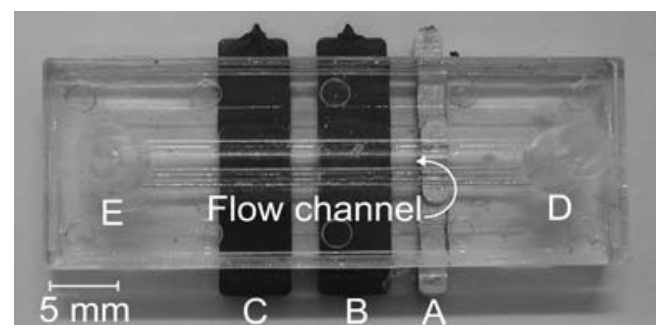

Fig. 1 The injection-moulded electrochemical micro flow cell. Here $(A)$ is the $\mathrm{Ag}$-coated electrode, which forms the reference $(\mathrm{Ag} / \mathrm{AgCl})$ element; $(B)$ is the working electrode, on which the bismuth film electrode is formed; $(C)$ is the auxiliary electrode; $(D)$ is the device inlet and $(E)$ is the device outlet. The flow channel is $1 \mathrm{~mm} \times 1 \mathrm{~mm}$ and $30 \mathrm{~mm}$ long auxiliary electrodes were $5 \mathrm{~mm}$ wide, the reference was $2 \mathrm{~mm}$ wide and the spacing between them was $2 \mathrm{~mm}$.

Reagents and solutions

All aqueous solutions were prepared using $>18 \mathrm{M} \Omega$ water (Elga Maxima Ultra Pure, Vivendi, High Wycombe, UK). The acetate buffer was prepared from acetic acid (glacial 99.8\% AnalaR grade, BDH, Poole, UK) and sodium acetate (99+\% ACS grade, Aldrich, Gillingham, UK). The ammonium buffer was prepared from ammonium chloride $(99.8 \%$ AnalaR grade, BDH) and ammonium hydroxide (28-30\% $\mathrm{NH}_{3}$ ACS grade, Aldrich). Bismuth plating solutions were prepared with bismuth(III) nitrate pentahydrate $(99.999 \%$, Aldrich,) either in acetate buffer or with lithium bromide (99+\%, Aldrich) in hydrochloric acid (1 M volumetric standard, Riedel-de Haën, Gillingham, UK), as described in the "Procedure" section. The mercury plating solution was prepared in nitric acid from a 1000 ppm mercury(II) chloride $(98+\%$, Aldrich) stock solution, as described in the "Procedure" section. Sample solutions were made from cobalt (995 $\mu \mathrm{g} / \mathrm{l}$, Aldrich) and nickel (1 g/l, Fluka, Gillingham, UK) atomic absorption standards with dimethylglyoxime (99+\%, Acros, Loughborough, UK) and sodium nitrite $(97+\%$, Aldrich). The saturated $\mathrm{AgCl}$ solution was prepared from silver nitrate $(99.9 \%$ AnalaR grade, $\mathrm{BDH})$ in potassium chloride (99.5\% AnalaR grade, BDH). Nitric acid (2 M volumetric standard, Riedel-de Haën) was used for electrode cleaning, as described in the "Procedure" section.

\section{Procedure}

Formation of the $\mathrm{Ag} / \mathrm{AgCl}$ miniaturised reference electrode

Using an external auxiliary platinum wire located in the inlet of the microdevice, the $\mathrm{Ag}$ electrode was coated in $\mathrm{AgCl}$ (in saturated $\mathrm{KCl}$ solution that was also saturated with $\mathrm{AgCl}$ through the addition of a small quantity of $\mathrm{AgNO}_{3}$ ) at $2 \mathrm{~V}$ for $3 \mathrm{~s}$.

Ex situ electroplating of the BiFE on the rotating disc electrode (RDE)

Two electroplating solutions were investigated, (A) and (B).

(A) Acetate buffer $\mathrm{Bi}(\mathrm{III})$ plating solution. $100 \mathrm{ppm} \mathrm{Bi}$ (III) in $1 \mathrm{M}$ acetate buffer ( $\mathrm{pH} 4.5)$. Plated for 5 mins at $-1.0 \mathrm{~V}$ in a quiescent solution.

(B) $\mathrm{LiBr} / \mathrm{HCl} \mathrm{Bi(III)} \mathrm{plating} \mathrm{solution.} 0.02 \mathrm{M} \mathrm{Bi}(\mathrm{III})$ in $0.5 \mathrm{M} \mathrm{LiBr}$ and $1 \mathrm{M} \mathrm{HCl}$. Plated for $60 \mathrm{~s}$ at $-0.28 \mathrm{~V}$ in a quiescent solution.

The RDE was then carefully rinsed before transferring it to the analysis solution. 
In-line electroplating of the BiFE on the flow cell working electrode

Two electroplating solutions were investigated, (A) and (B).

(A) Acetate buffer Bi(III) plating solution. 100 ppm Bi in $0.1 \mathrm{M}$ acetate buffer ( $\mathrm{pH} 4.5$ ). Plated for $5 \mathrm{mins}$ at $-1.0 \mathrm{~V}$ at a flow rate of $37.1 \mu \mathrm{l} / \mathrm{s}$.

(B) $\mathrm{LiBr} / \mathrm{HCl} \mathrm{Bi(III)} \mathrm{plating} \mathrm{solution.} 0.02 \mathrm{M} \mathrm{Bi}(\mathrm{III})$ in $0.5 \mathrm{M} \mathrm{LiBr}$ and $1 \mathrm{M} \mathrm{HCl}$. Plated for $120 \mathrm{~s}$ at $-0.28 \mathrm{~V}$ at a flow rate of $37.1 \mu \mathrm{l} / \mathrm{s}$.

After formation of the BiFE, the plating flow stream was flushed with water and switched to the analysis stream.

\section{Bismuth film cleaning procedure}

The $\mathrm{Bi}(\mathrm{III})$ film was cleaned of the remaining adsorbed complexes by holding the electrode at a potential of $-1.3 \mathrm{~V}$ for $30 \mathrm{~s}$ in $0.1 \mathrm{M} \mathrm{HCl}$.

\section{Bismuth film removal}

Bi(III) films were removed by applying a conditioning potential at $+0.3 \mathrm{~V},-0.5 \mathrm{~V}$ and $0 \mathrm{~V}$ for $2 \times 50 \mathrm{~s}$ in a flowing solution of $0.1 \mathrm{M} \mathrm{HNO}_{3}$.

In-line plating of MFE on the flow cell working electrode

The $\mathrm{Hg}$ plating solution was $200 \mathrm{ppm}$ in $0.1 \mathrm{M} \mathrm{HNO}_{3}$. Plated for $120 \mathrm{~s}$ at $-1 \mathrm{~V}$ at a flow rate of $9 \mu \mathrm{l} / \mathrm{s}$. After film formation the cell was flushed with water and switched to the analysis stream.

\section{Mercury film cleaning procedure}

The film was cleaned at a potential of $-1.4 \mathrm{~V}$ for $10 \mathrm{~s}$ in $0.1 \mathrm{M} \mathrm{HNO}_{3}$.

\section{Mercury film removal}

Films were removed at $+0.8 \mathrm{~V}$ in a flowing solution of $0.1 \mathrm{M} \mathrm{HNO}_{3}$ for $60 \mathrm{~s}$.

\section{Results and discussion}

The in-line prepared BiFE was assessed for its suitability in performing CAdSV of $\mathrm{Co}$ (II) and $\mathrm{Ni}(\mathrm{II})$. Various parameters, such as flow rates, solution composition, plating parameters and square-wave conditions, were studied to investigate the electrochemical behaviour of the $\mathrm{Bi}(\mathrm{III})$ films prepared on the injection-moulded carbon fibre electrodes.
Investigation of the effect of flow rate during the plating and accumulation stages

Using the acetate buffer-based plating solution, i.e. the $100 \mathrm{ppm} \mathrm{Bi(III)}$ in $0.1 \mathrm{M}$ acetate buffer, the effect of varying the flow rate during BiFE plating procedure was examined at 20,25 and $37 \mu \mathrm{l} / \mathrm{s}$ by varying the height of the reservoir in the gravity-fed flow system (with sample conditions as given in Fig. 2). The maximum response was obtained for the stripping peaks at a flow rate of $37 \mu \mathrm{l} / \mathrm{s}$ and so this rate was subsequently employed in this study.

The effect of varying the flow rate during the accumulation stage on the peak heights of $\mathrm{Co}$ (II) and $\mathrm{Ni}$ (II) was studied over the range of $5.8-55.5 \mu \mathrm{l} / \mathrm{s}$; the results are depicted in Fig. 2. The response for $\mathrm{Co}$ (II) increased linearly with increasing flow rate with a slope of $-0.036 \mu \mathrm{As} / \mu \mathrm{l}$ and an intercept of $-1.26 \mu \mathrm{A}$ with a correlation coefficient $\left(R^{2}=\right.$ 0.96 ), whereas that for $\mathrm{Ni}(\mathrm{II})$ did not show significant variation. A flow rate of $37 \mu \mathrm{l} / \mathrm{s}$ was selected, as this gave an acceptable response without adverse peak broadening and was compatible with the BiFE plating step flow rate, thereby simplifying the instrumentation.

\section{Effect of composition of the BiFE plating solution}

Reported methods for AdSV of $\mathrm{Co}(\mathrm{II})$ and $\mathrm{Ni}$ (II) have generally employed acetate buffer ( $\mathrm{pH} 4.5)$ containing $100 \mathrm{mg} / \mathrm{l} \mathrm{Bi(III)} \mathrm{[15,} \mathrm{24,} \mathrm{26,} \mathrm{28].} \mathrm{However,} \mathrm{Królicka} \mathrm{et} \mathrm{al.}$ $[29,30]$ suggested the use of a bromide-modified plating solution. Hence, both plating solutions were assessed using the RDE and flow cell setups. Figure 3 depicts the differing

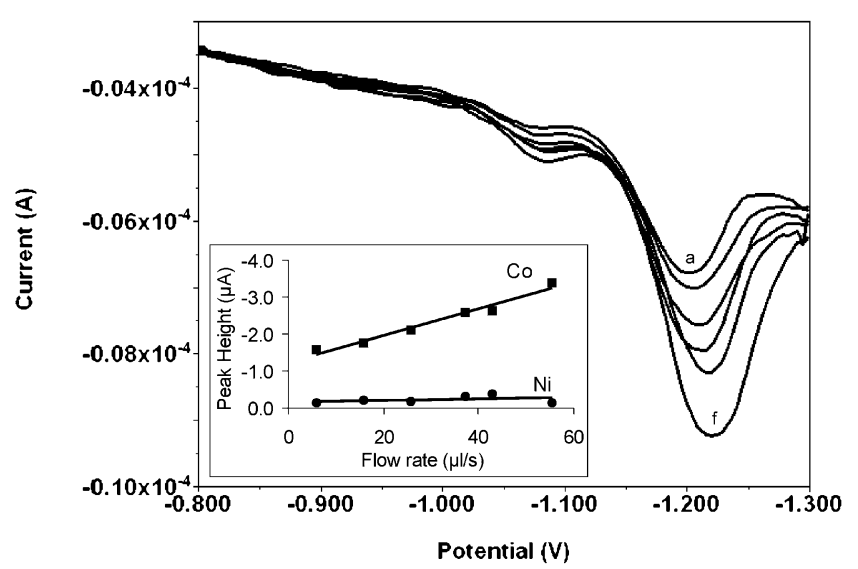

Fig. 2 Influence of flow rate during the accumulation stage on the $\mathrm{Ni}$ (II) and Co(II) CAdSV peaks, where the flow rates are: (a) 5.8, (b) 15.7, (c) $25.6,(d) 37.1,(e) 42.9$ and (f) $55.5 \mu \mathrm{l} / \mathrm{s}$ respectively. Carried out with a $10 \mathrm{ppb}$ sample of $\mathrm{Co}(\mathrm{II})$ and $\mathrm{Ni}(\mathrm{II})$ in $0.1 \mathrm{M}$ ammonium buffer ( $\mathrm{pH}$ 9.2) with $0.1 \mathrm{mM} \mathrm{DMG}$ and $0.5 \mathrm{M} \mathrm{NaNO}_{2}$. SW conditions: Conditioning potential $-1.3 \mathrm{~V}(10 \mathrm{~s})$, deposition potential $-0.8 \mathrm{~V}$ (120 s), equilibration time $5 \mathrm{~s}$, pulse frequency $15 \mathrm{~Hz}$, pulse amplitude $40 \mathrm{mV}$ and step potential $4 \mathrm{mV}$. Scan: initial $-0.8 \mathrm{~V}$ to end potential -1.3 V. Data were smoothed with a level-2 Savitzky-Golay filter 
performances of the two plating solutions. The $\mathrm{LiBr}$ containing plating solution gave the best stripping responses on both the RDE and the flow cell and was therefore used for subsequent studies.

Effect of solution parameters on the system behaviour

Buffer concentration The effect of changing the ammonium buffer concentration over the range $0-0.5 \mathrm{M}$ is shown in Fig. $4 \mathrm{a}$. Increasing the buffer concentration over the range $0-0.1 \mathrm{M}$ had a marked effect on the height of the $\mathrm{Co}$ (II) peak, but increasing the concentration further did not improve the peak height due to the increased background signal. As $\mathrm{Co}(\mathrm{II})$ and $\mathrm{Ni}(\mathrm{II})$ were sufficiently resolved at $0.1 \mathrm{M}$, this concentration was selected for all further experiments.

Effect of DMG concentration Figure $4 \mathrm{~b}$ shows the effect of increasing DMG concentration, over the range 0.01$0.35 \mathrm{mM}$, on the peak current. The Co(II) signal increases
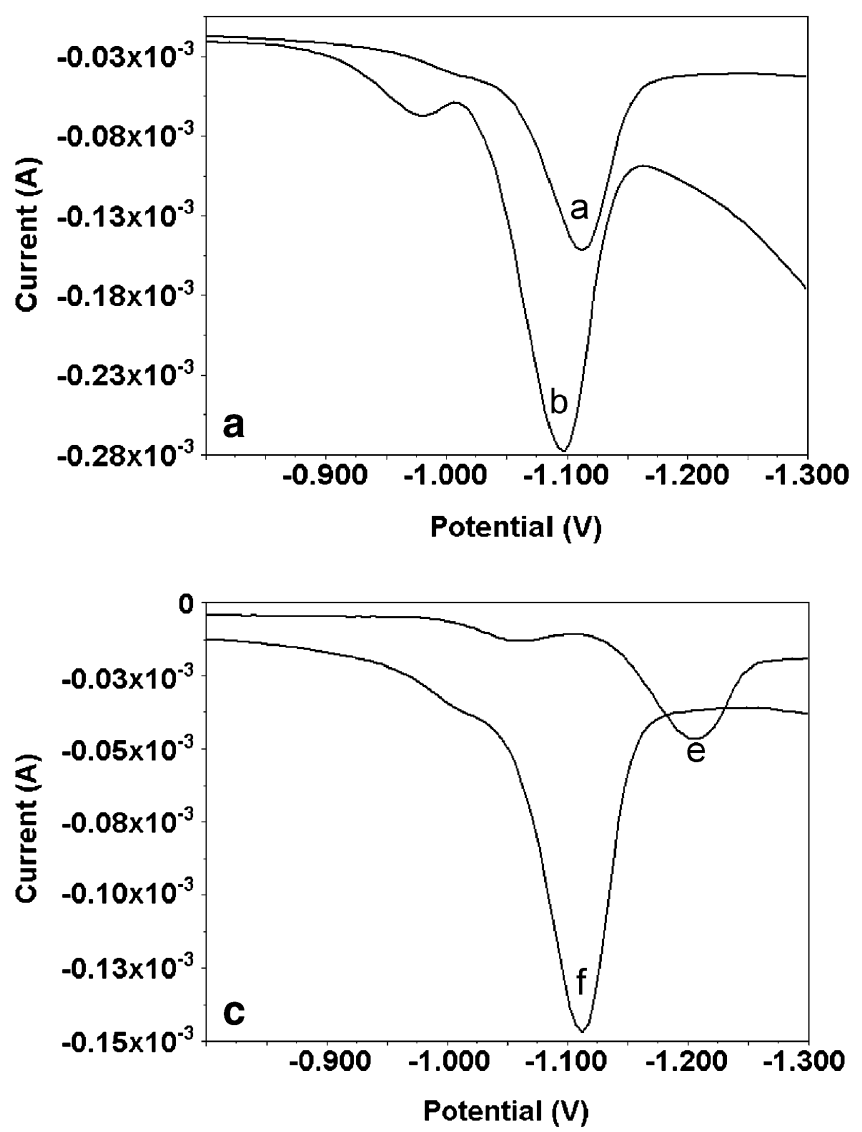

Fig. 3 Comparison of different $\mathrm{Bi}(\mathrm{III})$ plating solutions. a Effect of (a) $100 \mathrm{ppm} \mathrm{Bi(III)} \mathrm{in} \mathrm{acetate} \mathrm{buffer} \mathrm{(1} \mathrm{M,} \mathrm{pH} \mathrm{4.5)} \mathrm{and} \mathrm{(b)} 0.02 \mathrm{M} \mathrm{Bi}$ (III) in $0.5 \mathrm{M} \mathrm{LiBr}$ - and $1 \mathrm{M} \mathrm{HCl}$-based preplating solutions on RDE at $500 \mathrm{rpm}$. b Effect of $(c)$ the acetate buffer $(0.1 \mathrm{M}, \mathrm{pH} 4.5)$ and $(d)$ $\mathrm{LiBr} / \mathrm{HCl}$ preplating solutions on the flow cell. c Comparision of acetate buffer $\mathrm{pH} 4.5 \mathrm{Bi}(\mathrm{III})$ preplating solution on $(e)$ flow cell $(0.1 \mathrm{M})$ and $(f) \mathrm{RDE}(1 \mathrm{M})$. d Comparison of $\mathrm{LiBr}$ preplating solution almost linearly with increasing DMG concentrations, whereas the signal for $\mathrm{Ni}(\mathrm{II})$ steadily decreased to $0.2 \mathrm{mM}$ whereupon it levelled off. The signal for the Co(II) peak shifted to a slightly more negative potential $(-4 \mathrm{mV})$ than that for $\mathrm{Ni}(\mathrm{II})$ with increasing concentration. A concentration of $0.3 \mathrm{mM}$ was employed in the subsequent studies.

Effect of nitrite concentration Figure 4c shows the influence of nitrite concentration on the sample signal. The Co (II) signal shows a rapid increase in signal to $0.3 \mathrm{M}$ and a slower increase thereafter, whereas the $\mathrm{Ni}(\mathrm{II})$ peak height remained level to a concentration of $0.6 \mathrm{M}$. Concentrations of greater than $0.6 \mathrm{M}$ lead to increased background current and so a nitrite concentration of $0.5 \mathrm{M}$ was subsequently employed. Figure 5 shows the results obtained from the addition of nitrite to the sample system. Addition of nitrite to separate samples of $\mathrm{Ni}(\mathrm{II})$ and $\mathrm{Co}(\mathrm{II})$ results in increases in response for both metals, Fig. 5a and b, whereas the addition of nitrite to a mixture of $10 \mathrm{ppb} \mathrm{Co}(\mathrm{II})$ and $\mathrm{Ni}$ (II) results in an almost unchanged $\mathrm{Ni}$ (II) peak height whilst that for
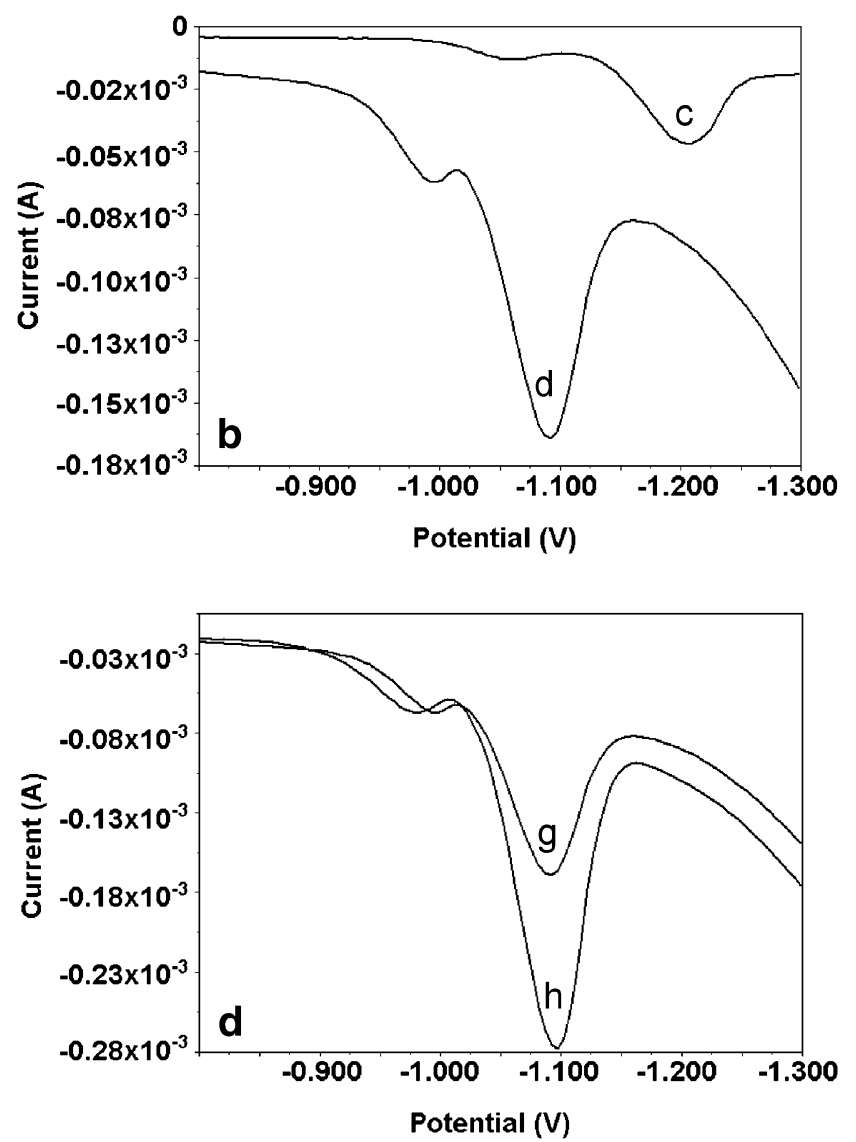

on $(g)$ flow cell and $(h)$ RDE. Carried out with a $10 \mathrm{ppb}$ sample of Co (II) and $\mathrm{Ni}(\mathrm{II})$ in $0.1 \mathrm{M}$ ammonium buffer ( $\mathrm{pH} 9.2$ ) with $0.1 \mathrm{mM}$ DMG and $0.5 \mathrm{M} \mathrm{NaNO}_{2}$. SW conditions: Conditioning potential $-1.3 \mathrm{~V}(10 \mathrm{~s})$, deposition potential $-0.8 \mathrm{~V}(120 \mathrm{~s})$, equilibration time $10 \mathrm{~s}$, pulse frequency $25 \mathrm{~Hz}$, pulse amplitude $50 \mathrm{mV}$ and step potential $5 \mathrm{mV}$ (except trace (e) which was at $15 \mathrm{~Hz}, 40$ and $4 \mathrm{mV}$ respectively). Scan: initial $-0.8 \mathrm{~V}$ to end potential $-1.3 \mathrm{~V}$ 

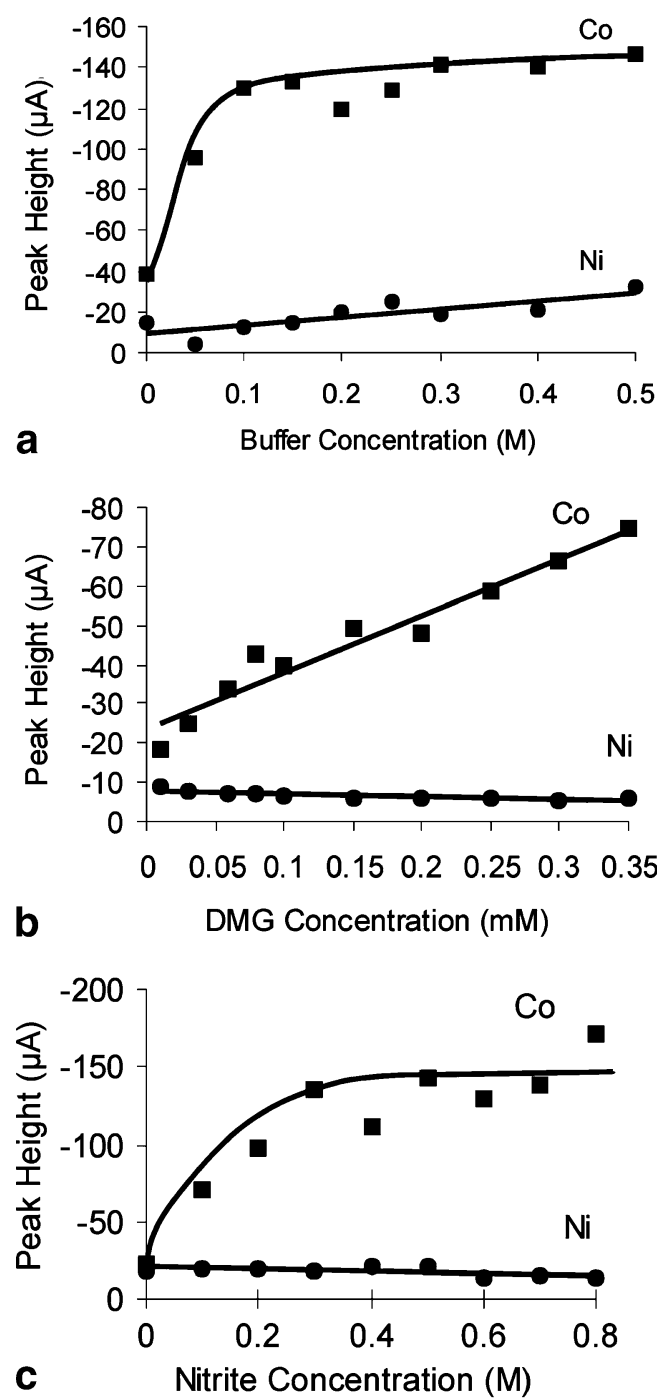

Fig. 4 Effect of solution parameters on the CAdSV behaviour of a $10 \mathrm{ppb} \mathrm{Co}$ (II) and Ni(II) sample: (a) ammonium buffer (pH 9.2) concentration over the range $0-0.5 \mathrm{M}$, (b) DMG concentration over the range $0-0.35 \mathrm{M}$ and (c) nitrite concentration over the range $0-0.8 \mathrm{M}$. Supporting electrolyte conditions were: (b and c) $0.1 \mathrm{M}$ ammonium buffer (pH 9.2), (a and c) $0.1 \mathrm{mM} \mathrm{DMG}$ and (a and b) $0.5 \mathrm{M} \mathrm{NaNO}_{2}$. SW conditions were: conditioning potential $-1.3 \mathrm{~V}(10 \mathrm{~s})$, deposition potential $-0.8 \mathrm{~V}(120 \mathrm{~s})$, equilibration time $10 \mathrm{~s}$, pulse frequency $25 \mathrm{~Hz}$, pulse amplitude $40 \mathrm{mV}$ (except c: $50 \mathrm{mV}$ ) and step potential $4 \mathrm{mV}$ (except c: $5 \mathrm{mV}$ ). Scan: initial $-0.8 \mathrm{~V}$ to end potential $-1.3 \mathrm{~V}$

Co(II) has increased elevenfold, Fig. 5c. Figure 5 d shows the reduction (16.6\%) of the $\mathrm{Co}$ (II) peak height upon the addition of $10 \mathrm{ppb} \mathrm{Ni}(\mathrm{II})$, while Fig. 5e displays the reduction (51.9\%) of the $\mathrm{Ni}$ (II) peak height upon the addition of $10 \mathrm{ppb} \mathrm{Co}(\mathrm{II})$.

Effect of varying the square-wave (SW) stripping parameters

Frequency The effect of frequency was studied in the range $12.5-100 \mathrm{~Hz}$, Fig. 6a depicts the results obtained. The peak heights for both metals increased with increasing SW frequency (as expected from increasing the effective scan rate) and shifted towards more negative values. However, increasing the frequency leads to insufficient time for the background current to decay and leads to an increase in the contribution to the signal and hence a distortion in peak shape. A frequency of $25 \mathrm{~Hz}$ was generally the maximum employed.

Step potential Figure $6 \mathrm{~b}$ shows the effect of the step potential on the peak heights. The response for Co(II) rose rapidly with rising step potentials (i.e. with an increase in effective scan rate) up to $3 \mathrm{mV}$ and thereafter levelled off, whereas the response for $\mathrm{Ni}(\mathrm{II})$ increased slowly to $7 \mathrm{mV}$. Peak resolution remained the same across this step potential range, with both peaks shifting towards more negative potentials. Values of 4 or $5 \mathrm{mV}$ were generally found to be ideal for adequate peak definition.

Amplitude The effect of the SW pulse amplitude was studied over the range 5-80 $\mathrm{mV}$. Both peaks shifted to more positive values, see Fig. $6 \mathrm{c}$ and they both initially increased rapidly in height $(5-20 \mathrm{mV})$ whereupon the responses for $\mathrm{Co}$ (II) and $\mathrm{Ni}$ (II) levelled off as a result of the increase in contribution from the background current. A SW pulse amplitude of either 40 or $50 \mathrm{mV}$ was employed.

Deposition potential Figure 6d shows the influence of the deposition potential on the peak currents. At potentials less than $-0.4 \mathrm{~V}$ the $\mathrm{Ni}$ (II) signal is completely suppressed and the Co(II) signal was markedly reduced due to the oxidation of the bismuth film (at around $-0.46 \mathrm{~V}$ in alkaline solutions). Both peaks gradually increase with potential in the range of $-0.4 \mathrm{~V}$ to a maximum at $-0.8 \mathrm{~V}$ and then exhibit a sharp reduction in adsorption at a more negative potential of $-0.9 \mathrm{~V}$ resulting from further reduction of the analyte complex. A deposition potential of $-0.8 \mathrm{~V}$ was selected, as this gave the maximum response for both metals.

Accumulation time The influence of the accumulation time on the stripping signal was examined. Figure 6e depicts the response in peak currents for $10 \mathrm{ppb}$ each of $\mathrm{Ni}(\mathrm{II})$ and $\mathrm{Co}$ (II). For both $\mathrm{Co}(\mathrm{II})$ and $\mathrm{Ni}(\mathrm{II})$ the response increases with accumulation time up to $150 \mathrm{~s}$ for $\mathrm{Co}(\mathrm{II})$ and $180 \mathrm{~s}$ for $\mathrm{Ni}$ (II), after which the response levels off, indicating saturation of the surface. An accumulation time of $120 \mathrm{~s}$ was used for subsequent measurements as this gave the best compromise between sensitivity and analysis time.

Analytical characterisation

The simultaneous determination of $\mathrm{Co}$ (II) and $\mathrm{Ni}$ (II) over the concentration range of 1-20 ppb was investigated. The determination was carried out in $0.1 \mathrm{M}$ ammonium buffer 

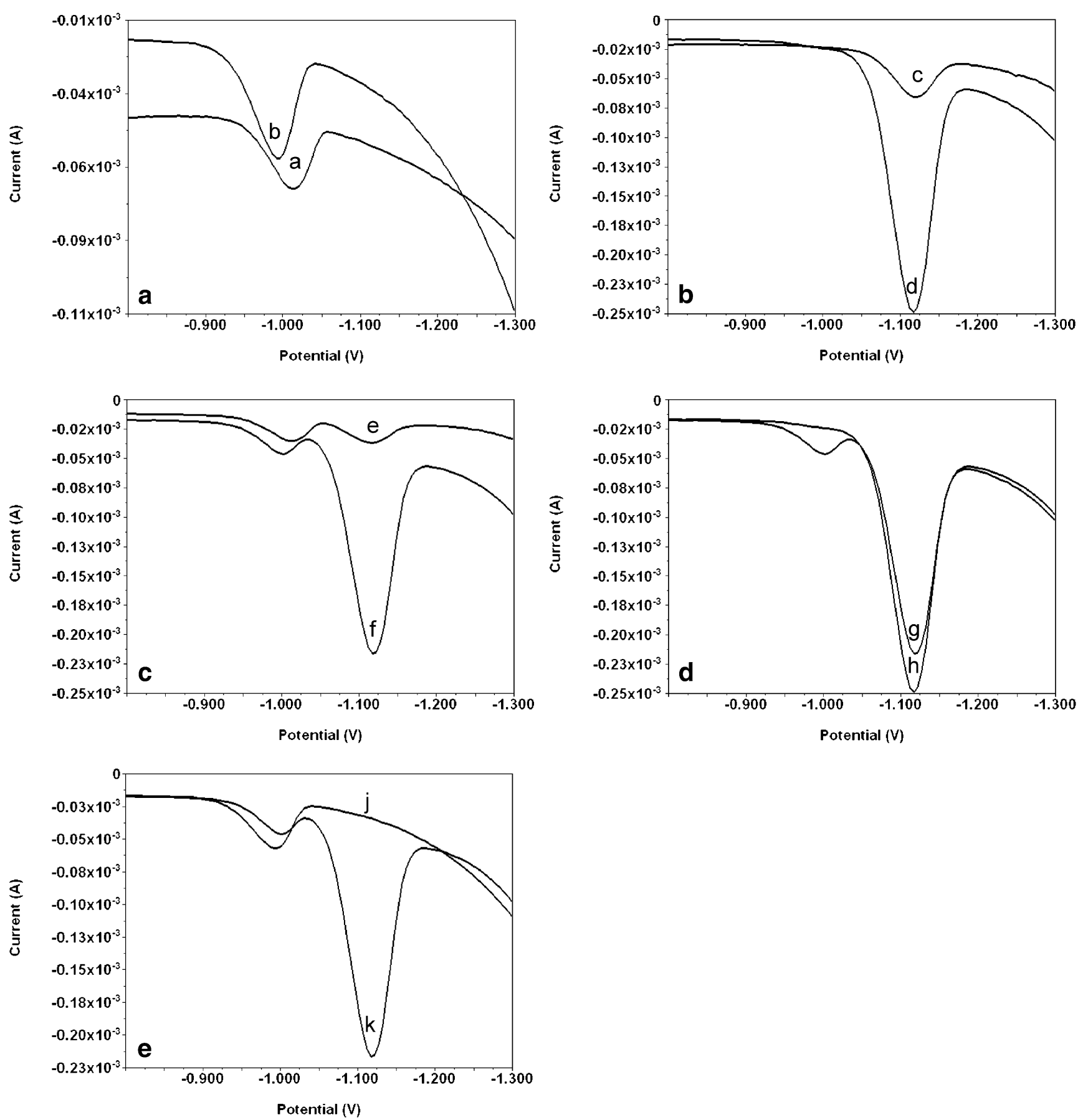

Fig. 5 a Effect of nitrite on stripping peak for $10 \mathrm{ppb} \mathrm{Ni}(\mathrm{II})$ when $(a)$ no $\mathrm{NaNO}_{2}$ is present; (b) $0.5 \mathrm{M} \mathrm{NaNO}_{2}$ is present. b Effect of nitrite on stripping peak for $10 \mathrm{ppb} \mathrm{Co}$ (II) when (c) no $\mathrm{NaNO}_{2}$ is present; $(d)$ $0.5 \mathrm{M} \mathrm{NaNO}_{2}$ is present. $\mathbf{c}$ Effect of nitrite on the stripping peaks for $10 \mathrm{ppb} \mathrm{Co}(\mathrm{II})$ and $\mathrm{Ni}(\mathrm{II})$ when (e) no $\mathrm{NaNO}_{2}$ is present; $(f) 0.5 \mathrm{M}$ $\mathrm{NaNO}_{2}$ is present. d Effect of addition of $10 \mathrm{ppb} \mathrm{Ni(II)}$ on the peak height for $10 \mathrm{ppb} \mathrm{Co}$ (II) in the presence of $0.5 \mathrm{M} \mathrm{NaNO}_{2}$ when $(h) \mathrm{Co}$ (II) only is present and ( $g$ ) both $\mathrm{Co}(\mathrm{II})$ and $\mathrm{Ni}(\mathrm{II})$ are present. e Effect

(pH 9.2) with $0.1 \mathrm{mM}$ DMG and $0.5 \mathrm{M} \mathrm{NaNO}_{2}$. SW conditions: conditioning potential $-1.3 \mathrm{~V}(10 \mathrm{~s})$, deposition potential $-0.8 \mathrm{~V}(120 \mathrm{~s})$, equilibration time $5 \mathrm{~s}$, pulse frequency $25 \mathrm{~Hz}$, pulse amplitude $50 \mathrm{mV}$ and step potential of addition of $10 \mathrm{ppb} \mathrm{Co}$ (II) on the peak height for $10 \mathrm{ppb} \mathrm{Ni}(\mathrm{II})$ in the presence of $0.5 \mathrm{M} \mathrm{NaNO}_{2}$ when $(j) \mathrm{Ni}$ (II) only is present and $(k) \mathrm{Co}$ (II) and $\mathrm{Ni}(\mathrm{II})$ are present. Carried out in $0.1 \mathrm{M}$ ammonium buffer $(\mathrm{pH}$ 9.2) with $0.1 \mathrm{mM}$ DMG. SW conditions: conditioning potential $-1.3 \mathrm{~V}(10 \mathrm{~s})$, deposition potential $-0.8 \mathrm{~V}(120 \mathrm{~s})$, equilibration time $5 \mathrm{~s}$, pulse frequency $25 \mathrm{~Hz}$, pulse amplitude $50 \mathrm{mV}$ and step potential $5 \mathrm{mV}$. Scan: initial $-0.8 \mathrm{~V}$ to end potential $-1.3 \mathrm{~V}$

$5 \mathrm{mV}$. Scan: initial $-0.8 \mathrm{~V}$ to end potential $-1.3 \mathrm{~V}$. The BiFE exhibited a well-defined response to changing concentration and the peak current response $(y, \mu \mathrm{A})$ was linear over the concentration range $(x, \mathrm{ppb})$ of $1-20 \mathrm{ppb}$, as expressed in the 

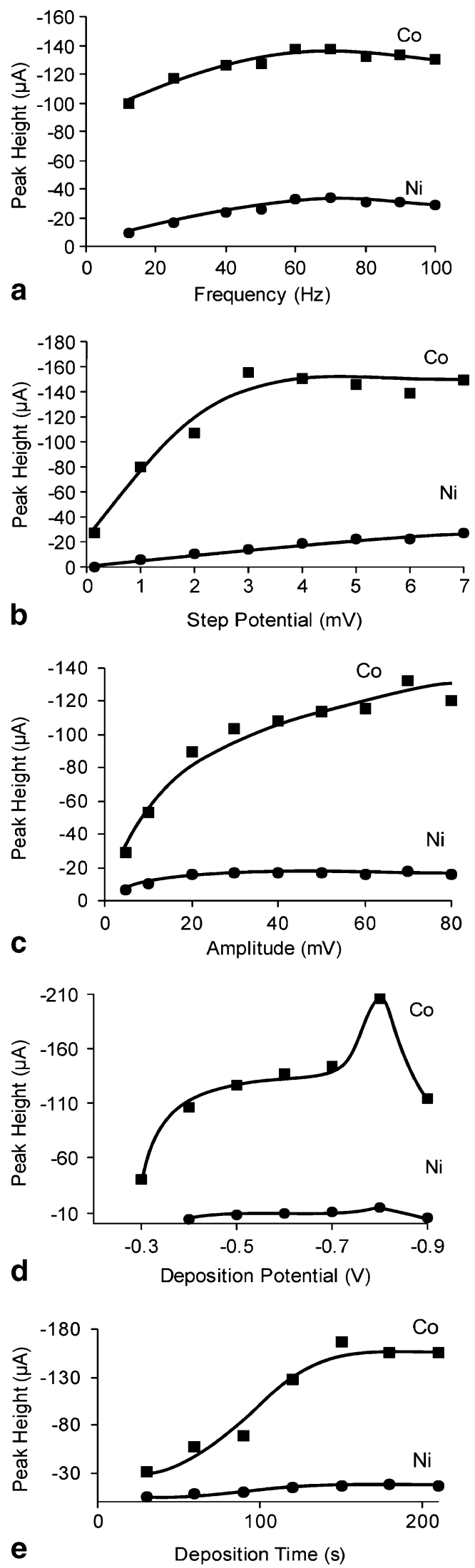

Fig. 6 Effect of varying the SW stripping parameters on the CAdSV peaks of a $10 \mathrm{ppb} \mathrm{Co}(\mathrm{II})$ and $\mathrm{Ni}$ (II) sample. The variables are (a) frequency $(12.5-100 \mathrm{~Hz})$, (b) step potential $(0.15-7 \mathrm{mV}),(\mathbf{c})$ amplitude $(5-70 \mathrm{mV}),(\mathbf{d})$ deposition potential $(-0.3$ to $-0.9 \mathrm{~V})$, (e) deposition time (30-210 s). Supporting electrolyte: $0.1 \mathrm{M}$ ammonium buffer ( $\mathrm{pH} 9.2$ ) with $0.1 \mathrm{mM} \mathrm{DMG}$ and $0.5 \mathrm{M} \mathrm{NaNO}_{2}$. SW conditions were (unless being investigated as above): conditioning potential $-1.3 \mathrm{~V}(10 \mathrm{~s})$, deposition potential $-0.8 \mathrm{~V}(120 \mathrm{~s})$, equilibration time $5 \mathrm{~s}$, frequency $25 \mathrm{~Hz}$, pulse amplitude $50 \mathrm{mV}$ (except b and e: $40 \mathrm{mV}$ ) and step potential $5 \mathrm{mV}$ (except e: $4 \mathrm{mV}$ ). Scan: initial $-0.8 \mathrm{~V}$ to end potential $-1.3 \mathrm{~V}$

calibration plots for $\mathrm{Co}(\mathrm{II}), y=-11.4 x-85.5\left(R^{2}=0.96\right)$, and $\mathrm{Ni}(\mathrm{II}), y=-1.64 x-7.20\left(R^{2}=0.92\right)$, respectively.

The stability of the BiFE formed on the injectionmoulded substrates was investigated by performing replicate runs on the same film. Ten replicate runs gave an average peak height for $\mathrm{Ni}$ (II) of $-1.05 \pm 0.10 \times 10^{-5} \mathrm{~A}$ (rsd: $9.6 \%$ ) and for $\mathrm{Co}(\mathrm{II})-8.19 \pm 0.82 \times 10^{-5} \mathrm{~A}$ (rsd: $10.0 \%$ ).

To compare the working electrode behaviour, AdSV and CAdSV of $\mathrm{Co}$ (II) and $\mathrm{Ni}$ (II) were also performed at a MFE in the flow cell. The solutions needed to be deaerated before analysis on the MFE. Neither AdSV or CAdSV of $\mathrm{Co}(\mathrm{II})$ on a MFE was possible in these particular flow cells due to a significant shift in the stripping peak to an extreme cathodic potential $(<-1.4 \mathrm{~V}$ vs $\mathrm{Ag} / \mathrm{AgCl})$, which led to analytical uncertainty at the edge of the supporting electrolyte potential window. However, AdSV of Ni(II) was possible, as illustrated in Fig. 7. It has been noted previously by this group $[57,58]$ that the main drawback with MFEs is the difficulty involved in regenerating the active mercury surface after use, necessitating the inclusion of cleaning and mercury film renewal procedures. In contrast to the MFEs, the BiFEs formed in these flow cells

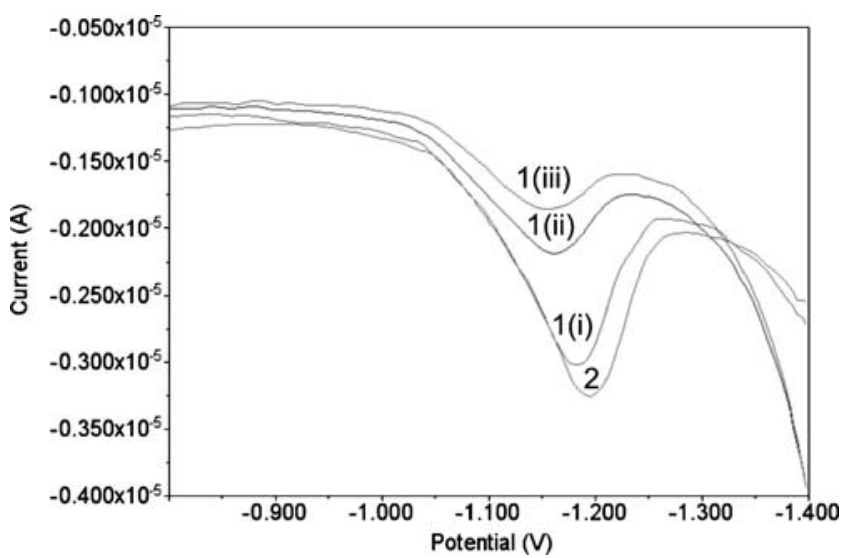

Fig. 7 AdSV of Ni(II) on a mercury film electrode. Here decimal numerals indicate the film number and roman numerals indicate replicate analyses carried out on the same film. Carried out with a $200 \mathrm{ppb}$ sample in $0.1 \mathrm{M}$ ammonium buffer $(\mathrm{pH} 9.3)$ with $0.1 \mathrm{mM}$ DMG (deaerated) at a flow rate of $16 \mu \mathrm{l} / \mathrm{s}$. SW conditions: conditioning potential $-1.4 \mathrm{~V}(10 \mathrm{~s})$, deposition potential $-0.5 \mathrm{~V}$ (200 s), equilibration time $5 \mathrm{~s}$, pulse frequency $25 \mathrm{~Hz}$, pulse amplitude $10 \mathrm{mV}$ and step potential $4 \mathrm{mV}$. Scan: $-0.5 \mathrm{~V}$ to end potential $-1.4 \mathrm{~V}$. Data were smoothed with a level-2 Savitzky-Golay filter 
enabled the generation of reproducible, quantitative analytical data, due to the enhanced stability of the bismuth films during the cleaning cycles, and the reduced cathodic potential for the cobalt stripping peak.

\section{Conclusions}

The application of a BiFE for the determination of $\mathrm{Co}$ (II) and $\mathrm{Ni}$ (II) by square-wave CAdSV under flow conditions in a non-deaerated solution has been demonstrated. The injection-moulded carbon-fibre-filled polystyrene electrodes have proven to be suitable supports for the formation of bismuth films. The LiBr-containing plating solution was found to offer superior performance for both the RDE and the flow cell under the alkaline conditions required for CAdSV. The application of a flow stable BiFE in an inexpensive sensor system permits the possibility of autonomous on-site industrial and environmental monitoring. The inherent disposability of the devices coupled with their mercury-free status should advance the scope of the sensor to point-of-care clinical applications.

Acknowledgements The authors would like to express their thanks to the following for financial support: EPSRC (SJB), Petroleum University of Technology, Ahwaz, Iran (NGN) and the University of Athens, Greece (AE).

Open Access This article is distributed under the terms of the Creative Commons Attribution Noncommercial License which permits any noncommercial use, distribution, and reproduction in any medium, provided the original author(s) and source are credited.

\section{References}

1. Bonfil Y, Brand M, Kirowa-Eisner E (1999) Anal Chim Acta 387:85-95

2. Bonfil Y, Brand M, Kirowa-Eisner E (2002) Anal Chim Acta 464:99-114

3. Bonfil Y, Kirowa-Eisner E (2002) Anal Chim Acta 457:285-296

4. Nolan MA, Kounaves SP (1999) Anal Chem 71:3567-3573

5. Brainina KZ, Kubysheva IV, Miroshnikova EG, Parshavkov SI, Maksimov YG, Volkonsky AE (2001) Field Anal Chem Technol 5:260-271

6. Wagner K, Strojek JW, Koziel K (2002) Electroanalysis 15:392-397

7. Honeychurch KC, Hart JP (2003) TrAC 22:456-469

8. Wang J, Lu J, Hočevar SB, Farias PAM, Ogorevc B (2000) Anal Chem 72:3218-3222

9. Swedish Chemicals Inspectorate (KEMI) (2004) Mercury: investigation of a total ban (KEMI report No 4/04). KEMI, Stockholm. http://www.kemi.se/upload/Trycksaker/Pdf/Rapporter/Rapport4 04. pdf, accessed 23rd October 2007

10. European Commission (2005) Commision proposes strategy to deal with mercury pollution including a ban on exports (Press Release IP/ 05/114). EC, Brussels. http://europa.eu.int/rapid/pressReleasesAction. do? reference $=\mathrm{IP} / 05 / 114 \&$ format $=$ HTML\&aged $=0$ \&language $=\mathrm{EN} \&$ guiLanguage $=$ en, accessed 23rd October 2007
11. European Parliament, Committee on the Environment, Public Health and Food Safety (2007) Mercury: ban exports and make storage safer (Press Release REF.: 20070502IPR06205). European Parliament, Strasbourg. http://www.europarl.europa.eu/news/ expert/infopress page/064-6215-122-05-18-911-20070502IPR0620502-05-2007-2007-false/default_en.htm, accessed 23rd October 2007

12. Wittstock G, Strübing A, Szargan R, Werner G (1998) J Electroanal Chem 444:61-73

13. Hočevar SB, Ogorevc B, Wang J, Pihlar B (2002) Electroanalysis 14:1707-1712

14. Baldo MA, Daniele S, Bragato C (2003) J Phys (Paris) IV 107:103-106

15. Wang J, Lu J (2000) Electrochem Commun 2:390-393

16. Wang J, Lu J, Kirgöz UA, Hočevar SB, Ogorevc B (2001) Anal Chim Acta 434:29-34

17. Hutton EA, Ogorevc B, Hočevar SB, Weldon F, Smyth MR, Wang J (2001) Electrochem Commun 3:707-711

18. Wang J, Kirgöz UA, Lu J (2001) Electrochem Commun 3:703-706

19. Wang J, Deo RP, Thongngamdee S, Ogorevc B (2001) Electroanalysis $13: 1153-1156$

20. Hočevar SB, Wang J, Deo RP, Ogorevc B (2002) Electroanalysis $14: 112-115$

21. Lin L, Lawrence NS, Thongngamdee S, Wang J, Lin Y (2005) Talanta 65:144-148

22. Kefala G, Economou A, Voulgaropoulos A, Sofoniou M (2003) Talanta 61:603-610

23. Kefala G, Economou A, Voulgaropoulos A (2004) Analyst 129:1082-1090

24. Morfobos M, Economou A, Voulgaropoulos A (2004) Anal Chim Acta 519:57-64

25. Chatzitheodorou E, Economou A, Voulgaropoulos A (2004) Electroanalysis 16:1745-1754

26. Hutton EA, Hočevar SB, Ogorevc B, Smyth MR (2003) Electrochem Commun 5:765-769

27. Hutton EA, Ogorevc B, Smyth MR (2004) Electroanalysis $16: 1616-1621$

28. Hutton EA, van Elteren JT, Ogorevc B, Smyth MR (2004) Talanta 63:849-855

29. Krolicka A, Bobrowski A, Kalcher K, Mocak J, Švancara I, Vytřas K (2003) Electroanalysis 15:1859-1863

30. Królicka A, Bobrowski A (2004) Electrochem Commun 6:99-104

31. Maghasi AT, Halsall HB, Heineman WR, Rodriguez Rilo HL (2004) Anal Biochem 326:183-189

32. Guo Z, Feng F, Hou Y, Jaffrezic-Renault N (2005) Talanta 65:1052-1055

33. Demetriades D, Economou A, Voulgaropoulos A (2004) Anal Chim Acta 519:167-172

34. Krolicka A, Pauliukaite R, Švancara I, Metelka R, Bobrowski A, Norkus E, Kalcher K, Vytřasfs K (2002) Electrochem Commun 4:193-196

35. Vytřas K, Švancara I, Metelka R (2002) Electroanalysis 14:1359-1364

36. Flechsig G-U, Korbout O, Hočevar SB, Thongngamdee S, Ogorevc B, Gründler P, Wang J (2002) Electroanalysis 14:192-196

37. Wang J, Lu J, Hočevar SB, Ogorevc B (2001) Electroanalysis 13:13-16

38. Kadara RO, Tothill IE (2004) Anal Bioanal Chem 378:770-775

39. Banks CE, Kruusma J, Moore RR, Tomčík P, Peters J, Davis J, Komorsky-Lovric Š, Compton RG (2005) Talanta 65:423-429

40. Pauliukaite R, Metelka R, Švancara I, Królicka A, Bobrowski A, Vytřas K, Norkus E, Kalcher K (2002) Anal Bioanal Chem 374:1155-1158

41. Pauliukaite R, Hočevar SB, Ogorevc B, Wang J (2004) Electroanalysis $16: 719-723$

42. Economou A (2005) TrAC 24:334-340

43. Charalambous A, Economou A (2005) Anal Chim Acta 547: $53-58$ 
44. Prior C, Walker GS (2006) Electroanalysis 18:823-829

45. Yong L, Armstrong KC, Dansby-Sparks RN, Carrington NA, Chambers JQ, Xue Z-L (2006) Anal Chem 78:7582-7587

46. Lin L, Thongngamdee S, Wang J, Lin Y, Sadik OA, Ly S-Y (2005) Anal Chim Acta 535:9-13

47. Kefala G, Economou A, Voulgaropoulos A (2006) Electroanalysis 18:223-230

48. Kefala G, Economou A, Sofoniou M (2005) Talanta 68:1013-1019

49. Wang J, Lu D, Thongngamdee S, Lin Y, Sadik OA (2005) Talanta 69:914-917
50. Wang J, Thongngamdee S, Lu D (2006) Electroanalysis 18:59-63

51. Kefala G, Economou A (2006) Anal Chim Acta 576:283-289

52. Economou A, Voulgaropoulos A (2007) Talanta 71:758-765

53. Vega M, van den Berg CMG (1997) Anal Chem 69:874-881

54. Colombo C, van den Berg CMG (1997) Anal Chim Acta 337:29-40

55. Bobrowski A, Zarębski J (2000) Electroanalysis 12:1177-1186

56. Mylonakis A, Economou A, Fielden PR, Goddard NJ, Voulgaropoulos A (2004) Electroanalysis 16:524-531

57. Economou A, Fielden PR (1997) TrAC 16:286-292

58. Economou A, Fielden PR (2003) Analyst 128:205-212 